\title{
Housing Fitting Economic Transition: Three Case Studies in Shenzhen and Shanghai
}

\author{
XU ANZHI \\ Shenzhen University \\ China
}

\section{INTRODUCTION}

China's economy is developing very quickly. Shanghai and Shenzhen, the most vigorous cities, are progressing from a planned economy to a market economy. Their economies are progressing from a comparatively well-off condition to a wealthy condition. Housing facilities are crossing or will cross over from the former condition of "no car, no elevator" to a newer condition of "cars in the family" and "elevators in multi-storey housing." How can Chinese architects do their job for varied types of housing to fit this transitional situation?

\section{PART I. HOUSING REFORM IN CHINA PROMOTES THE NEW TYPES OF URBAN RESIDENCE}

In order to alleviate the shortage of urban residential supply, a new set of housing policies has been implemented since 1988. The reform seeks to turn the existing welfare system into merchandise system. By now there may exist three main types of urban residential housing in China.

\section{Welfare housing or public housing:}

It is open to the staffs in governmental agencies and public institutions like universities and schools. The buyers only have to pay the construction cost of the building (1000 yuan/ square meter in Shenzhen). These houses are not available for sale or rent.

\section{Low-profit housing:}

It is provided for those working in the state-owned companies and some social institutions.

The buyers have to pay the construction cost, land cost, and low profit (2500 yuan/square meter in Shenzhen). These houses can circulate within the qualified circle.

\section{Commodity housing:}

It is available in the market. Usually the buyers come from the senior staffs of foreign companies, heads of those small private companies and other nouveaux-riches. (3500-7000 yuan/square meter in Shenzhen)

\section{PART II. CASE STUDIES ON HOW HOUSING DESIGN FITS THE ECONOMIC TRANSITION}

The author will present three different housing design types and renewal works in Shenzhen and Shanghai. The content inlcudes the following three cases: Shenzhen Shennan Garden, Shenzhen University Staff Housing, and Shanghai Kangiian Housing. These different types of housing demonstrate how architects pay attention to the problems in the transitional, developmental period of the Chinese economic system. Exploratory methods will also be presented here.

\section{Case 1. Shenzhen Shennan Garden - How Commodity Housing Adapts to the Market}

Shennan Garden is locatet north adjacent to Shennan Road, one of most important expressways in Shenzhen. It has a view of Hongkong southward aross over the beautiful Shenzhen Bay. Several kilometers to its east lies the famous Oversea Chinese Town.

The complex consists of 8 highrise towers with a total space area of $250,000 \mathrm{~m}^{2}$, three of which are under construction. It was designed by a graduate group under the author's direction and won the final bid in 1992.

Considering the site situation, the group sets the principle that each flat face south and therefore the panoroma of the bay was adopted as an important element of family environment. In particular, the details of windows and balconies were much accounted for.

Enough parking spaces for cars and bicycles were arranged at the basement. As the land market was established, high land values are pushing parking lots farther away and parking problems are becoming increasingly inconvenient to urban residents. The considerate design of parking lots in Shennan Garden gave it an advantaged in the market.

A new structural system was adopted in each unit: an open shear wall plus beamless slab structure. The residents can freely partition the house. The architects also avoid the limits of column pattern and can make a flexible floor plan. The new system can satisfy different occupants' requirements. This case gives us a very good example of how commodity housing can adapt to the demands of the changing market. 


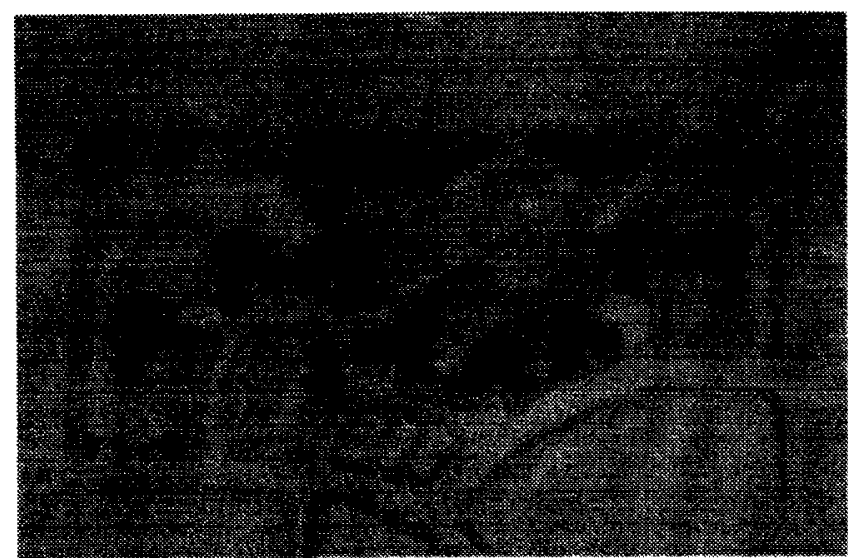

Figure 1. The master plan of Shenzhen Shennan Garden Highrise Housing

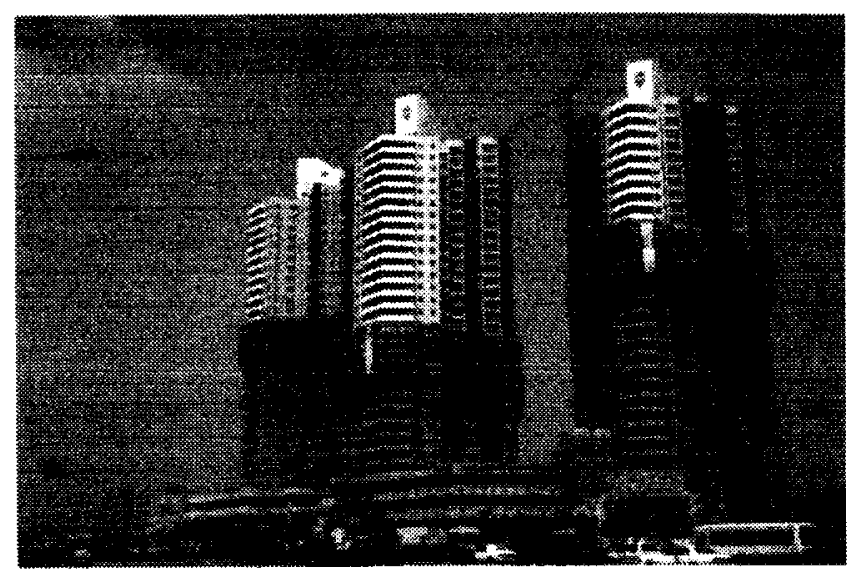

Figure 2. Shenzhen Shennan Garden Highrise Housing first phase under construction.

\section{Case 2. Shenzhen University Housing - How Welfare Housing Adapts to the User's Requirements}

There are regulations on development intensity in China. Furthermore the current housing reform strictly limits the floor space of a flat in welfare houses. How to increase the utility of floor space and create extra space is really concerned with the residents' interests, especially while Chinese people tend to have a big family.

The design group took the following approaches:

- beamless slab structure system

It is an effective way to enlarge the useful space: beamless slabs permit more efficient layout of furniture; open shear walls reduce the number and thickness of the walls quite a lot and provide the spacious living room which is increasingly appreciated by clients.

- Multi-storied flat

Multi-storied flats have been planned on the first and top floors of the buiding. The ceiling height was raised from $2.9 \mathrm{~m}$ to $4.8 \mathrm{~m}$ to permit the owner to add a second floor after completion. Fortunately, the current limits on floor space do not include this additional space.

\section{- Parking lots}

The general topography of the site is a slope down southwards. The buiding orientations are along the contours of the slope and then the first floors are uplifted to half-story height. Therefore the partly underground spaces come out of the floor space regulations and could be taken for different uses. In most cases the residents would like to turn it into parking lots because some of them are preparing to buy a car or even already possessed it. Occasionally these spaces could be rebuilt as an attachment of a flat. On the other hand, elevation of the first floor is also a good way to resist the local high humidity.

- Some special designs in detail parts

Widen windowsills and prolong the balcony length. Usually the ordinance only demonstrates the limits of overhanging span of constructions like ceilings, balcony, curtains, and so on.

This case demonstrates how architects cut down the structure area, make full use of the first and top floors to make more useful space in welfare housing.

\section{Case 3. Shanghai Kangjian Housing - How The Low-Profit Housing Can Be "Renewed" to Adapt to the Middle Class Requirements}

Kangjian housing is located southwest of Shanghai and had been ever promoted as one of the first 13 good examples of comprehensive residential developments in China. Actually the dwellings themselves were low-class houses constructed under the "National Residential Standards 1985" in the early planned economy $\rightarrow$ six-floor structure, flat size $40-60 \mathrm{~m}^{2}$ with neither sitting room nor elevator.

After buying the houses, many residents have independently updated their own housing.

- Some of them have bought the next apartment and combined the two apartments into a larger one which would have a big sitting room.

- To meet the needs of present and future requirements, the investment from all tenants was collected to install an elevator in the six-floor structure.

- Residents rebuilt the outside empty space to make a parking area. Even in a metropolis like Shanghai, where there is a perfect public transportation system, a private car is increasingly becoming a local fashion.

The above methods do not only provide convenience to the residents, but also offer meaningful experiments in updating housing from the previous low-standard to the current and future economic levels. Low standard housing occupies the largest portion in China. Most of it needs rebuilding. How to rebuild it? How to make it fit the requirements of the increasing demands of the residents? The experience in Kangjian housing renewal may help us find the answer.

\section{PART III. CONCLUSION}

Contempory architects should see to the demands of resi- 
dents from different classes in China, especially when they are doing housing design. As China is stepping from a planned economy into a market economy, the community class structure is increasingly differentiated. Today's planners and architects are learning to face the different clients and to achieve different goals in their designs: on one hand they keep up the effort to create more housing for the homeless; on the other hand they set about the experiment in urban housing renewal to meet the growing demands of the middle class in China.

Perhaps the above challenges also provide a good oppor- tunity for we planners and architects to update ourselves in the transitional period of the Chinese economy. That is the critical step we must stride out.

\section{ADDITIONAL SOURCES}

The Collection of China Urban Experimental Housing Design, China Architecture Press, 1994.

Housing in Long-Term Effectiveness, Jiang Pei-si, Southeast University Press, 1993.

Housing for the Year of 2000, Zhou Guan-qian, China Architecture Press, 1991. 